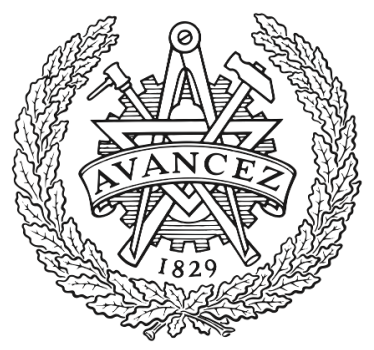

CHALMERS

UNIVERSITY OF TECHNOLOGY

\title{
Characterization of a dusting lime kiln - A mill study
}

Downloaded from: https://research.chalmers.se, 2023-04-26 10:52 UTC

Citation for the original published paper (version of record):

Dernegård, H., Brelid, H., Theliander, H. (2017). Characterization of a dusting lime kiln - A mill study. Nordic Pulp and Paper Research Journal, 32(1): 25-34.

http://dx.doi.org/10.3183/NPPRJ-2017-32-01-p025-034

N.B. When citing this work, cite the original published paper. 


\section{Characterization of a dusting lime kiln - A mill study}

\section{Henric Dernegård, Harald Brelid and Hans Theliander}

KEYWORDS: Lime kiln; Dust, Particle size; Specific surface area; Slaking.

SUMMARY: The white liquor preparation is one of the main purposes of the recovery cycle in a kraft pulp mill and the lime kiln, being the single unit operation handling bulk solid materials, poses particular challenges in the recovery cycle.

In this study, the influence of a dusting lime kiln on the preparation of white liquor was studied.

The investigation showed that the dusting lime kiln produced a burned lime with a substantial fraction of fines at the expense of the fraction of granules, whereas a clear lime kiln had virtually no fines and more granules instead.

Burned lime from both dusting and clear periods were collected and separated into fines and granules. The different fractions were slaked and causticized in a synthetic green liquor. The study found that the fines always delivered a lower effective alkali in the resulting white liquor, and that the particle sizes of the lime mud were always larger than those originating from the granules, implying that the fines were sintered harder.

The industrial consequence is that a dusting lime kiln increases the load on the kiln because the yield of effective alkali is lower; it also introduces a greater dead load into the liquor cycle.

\section{ADDRESSES OF THE AUTHORS:}

Henric Dernegård: henric.dernegard@sodra.com Södra Cell Mönsterås, Box 501, 38325 Mönsterås, Sweden.

Harald Brelid: harald.brelid@sodra.com Södra Innovation, SE-43286 Väröbacka, Sweden.

Hans Theliander: hanst@chalmers.se Chalmers University of Technology, Department of Chemistry and Chemical Engineering, Forest Products and Chemical Engineering, SE-412 96 Gothenburg, Sweden.

Corresponding author: Hans Theliander

In the kraft process, wood chips are digested with a cooking liquor containing $\mathrm{NaOH}$ and $\mathrm{Na}_{2} \mathrm{~S}$. During digestion, lignin is fragmented and dissolved, facilitating the liberation of cellulose fibres suitable for paper production. The spent cooking liquor is evaporated to a high dry solids content and burned in a recovery boiler for the regeneration of cooking chemicals and production of steam. The recovery boiler produces an inorganic salt smelt that is dissolved in water to form "green liquor", which contains $\mathrm{HS}^{-}, \mathrm{OH}^{-}$and $\mathrm{CO}_{3}{ }^{2-}$.

In the first step in converting $\mathrm{CO}_{3}{ }^{2-}$ to $\mathrm{OH}^{-}$, burned lime $(\mathrm{CaO})$ is added to the green liquor and is slaked according to $E q 1$.

$$
\mathrm{CaO}+\mathrm{H}_{2} \mathrm{O} \rightarrow \mathrm{Ca}(\mathrm{OH})_{2}
$$

This is an exothermal reaction and generates approx. 65 $\mathrm{kJ} / \mathrm{mol}$ (Sixta, 2006). The slaked lime reacts with the carbonate ions according to $E q 2$.

$$
\mathrm{CO}_{3}{ }^{2-}(\mathrm{aq})+\mathrm{Ca}(\mathrm{OH})_{2}(\mathrm{~s}) \rightarrow 2 \mathrm{OH}^{-}(\mathrm{aq})+\mathrm{CaCO}_{3}(\mathrm{~s})[2]
$$

This reaction is also slightly exothermal (Hanson, Theliander 1994a).

The lime kiln is the unit operation in the kraft process in which lime mud is calcined to reburned lime in order to close the calcium cycle. The lime kiln system consists of a rotary kiln, which is normally $70-100 \mathrm{~m}$ in length and has a diameter of approx. $4 \mathrm{~m}$. The reburning of lime is endothermic, and about $3 \mathrm{MJ}$ is required to produce $1 \mathrm{~kg}$ of pure $\mathrm{CaO}$ at $900^{\circ} \mathrm{C}$ (Hanson, Theliander 1994a). The lime mud is washed and dewatered using a vacuum drum filter and the dryness is increased from around 35 weight $\%$ to $75-85$ weight \%. In most Scandinavian lime mud handling systems, the moist lime mud is then dried in a flash drier utilizing hot flue gas from the kiln. The majority of the dry lime mud is separated from the flue gases in a cyclone; the carry-over following the gases is separated in a subsequent electrostatic precipitator (ESP). Finally, the solids from the cyclone and the ESP dust are fed into the lime kiln. An older system includes: lime kiln with wetscrubbers but without flash driers and ESP.

Numerous complex phenomena and process disturbances occur in the lime kiln that have been the subject of many studies. These phenomena include, for example, the occurrence of rings and balls (Lindblom et al. 1998), the enrichment of non-process elements disabling the lime mud to form $\mathrm{CaO}$ (Ulmgren, 1997) and the formation of burned lime granules with a certain diameter (Tran et al. 1991).

Hanson and Theliander (1994b) showed that the reactivity of burned lime is correlated to the specific surface area, which is a measure of the degree of sintering and, in turn, is affected by temperature, residence time, the presence of non-process elements and the composition of the gas. The specific surface area gives a good measure of the quality of the lime, i.e. whether it is a soft burned or hard burned lime. Their paper also showed that two distinct phases can be identified during slaking: an initial phase involving a rapid increase in temperature during the first minute and a much slower later phase.

Rydin et.al (1977) investigated how hard burned lime and soft burned lime respectively influenced the causticizing efficiency and the permeability of the lime mud sludge. It was concluded that hard burned lime have higher permeability than a lightly burned lime. It was also observed that the causticizing rate to some extent is governed by the quality of the lime.

A phenomenon that is often observed is dusting in the lime kiln, and is assumed to be associated with both the enrichment of non-process elements and the quality of the burned lime. Kassberg and Petersson (1997) state that dusting in the hot end of the lime kiln has a negative impact on both the heat transfer and its general performance. Mao and Tran (2016) argue that the main problem associated with dusting is the obscuration of the heat radiation, leading to unstable kiln operations. Furthermore, he reports that dust losses in the feed end of the lime mud are typically in the range of $5 \%$ to $20 \%$ of the dry mud feed 
rate, and that the extent of dusting is determined by the particle size of the solids, gas velocity and mud feed rate where the most important factor is particle size and depends ultimately on the degree of agglomeration. This is in agreement with the results obtained by Fardadi (2010), who modelled dust formation in the cold end of the kiln. She found that dusting depends on the lift force exerted on the solid particles, and therefore the flue gas velocity in combination with the particle size to be the most important factors.

It is quite common that mills have problems with dusting in lime kilns which may influence the quality of the reburned lime mud. Since the quality of reburned lime directly affects the preparation of white liquor, and thus the last stage in the chemical recovery process in a kraft pulp mill, particular attention should be paid to the impact a dusting lime kiln has on the production of white liquor. Nevertheless, no studies focusing on the effect of a dusting lime kiln on the preparation of white liquor are to be found in the literature.

In the present investigation, burned lime, lime mud and ESP dust from a clear and a dusting lime kiln have been characterized. The aim was twofold: to increase knowledge of the factors that influence the degree of dusting and to investigate the effect a dusting lime kiln has on the white liquor preparation process.

\section{Materials and Methods}

\section{Description of the kraft pulp mill}

Samples were taken from the Södra Cell mill in Mönsterås. The mill produces 750000 air dry metric tonnes (ADt) of fully bleached pulp per year, of which 200000 ADt are hardwood pulp and $550000 \mathrm{ADt}$ are softwood pulp. There are two lime kilns fired with $70 \%$ pulverized bark and 30\% tall oil pitch. Kiln No. 1 is 113 meters long, has an inner diameter of 3.3 meters and a production rate of 450 tonnes of burned lime per day. Kiln No.2 is 73.5 meters long, has an inner diameter of 2.8 meter and a production rate of this smaller lime kiln is 250 tonnes per day. Kiln 1 is equipped with a labyrinth cooler and Kiln 2 has satellite coolers. The calculated adiabatic flame temperature is about $1800^{\circ} \mathrm{C}$ for dry bark fuel and the flue gas temperature is about $700^{\circ} \mathrm{C}$ in the lime mud feed end. The lime production equates to $290 \mathrm{~kg}$ of burned lime per ADMT for softwood and 280 $\mathrm{kg}$ for hardwood pulp. Historically, Kiln 1 has been dusting whereas Kiln 2 has been clear. Since lifters were installed in September 2014, however, Kiln 2 has had dusting problems at uneven intervals. Simultaneously, significant increase in the dry content of the lime mud after the lime mud filter was observed. From September 2014 to September 2015, Kiln 2 has had six dusting periods, lasting between two and four weeks. This study investigated only Kiln 2. Starting in March 2015, burned lime, wet lime mud and ESP dust were sampled during clear and dusting periods. These samples were characterized with regard to chemical composition, particle size and specific surface area. In addition, samples of particular interest were investigated with a FEI Quanta200 ESEM (environmental scanning electron microscope).

\section{Chemical elements}

The wet lime mud, ESP dust and burned lime were analyzed for contents of $\mathrm{Ca}, \mathrm{Mg}, \mathrm{Mn}, \mathrm{Al}, \mathrm{Si}, \mathrm{P}, \mathrm{K}, \mathrm{Zn}$ and Fe. The samples were dissolved in equal parts of concentrated hydrochloric acid $(\mathrm{HCl})$ and water, before being analyzed in a PerkinElmer inductively-coupled plasma (ICP) Optical Emission Spectrometer Optima 7300 DV. Carbon and sulphur contents were determined by analyzing the $\mathrm{CO}_{2}$ and $\mathrm{SO}_{2}$ released during combustion using an ELTRA CS 800-instrument. The wet lime mud was also analyzed with regard to water-soluble sodium using a Sherwood flame photometer 410 (results not shown).

\section{Particle size}

The particle size distributions of the wet lime mud, lime mud from the flash dryer and ESP dust from the seven sampling periods were analyzed using a Malvern Mastersizer 2000.

\section{Sieving}

Sieving was carried out not only to quantify the degree of dusting but also to obtain two different fractions for the slaking and causticizing tests.

Burned lime from a dusting and a clear lime kiln was sieved using a woven wire standard test sieve. The dust fraction and the fraction between 10 and $15 \mathrm{~mm}$ were analyzed with regard to residual carbonates and chemical elements.

\section{Slaking and $A B C$-titration}

The aim was to study the kinetics rather than the equilibrium, so it was important to have both a green liquor of a predetermined composition and to perform causticizing at a lime charge far from the amounts needed to reach the chemical equilibrium (underliming). The lime charge for a desired effective alkali of the white liquor was therefore calculated.

A total of 25 grams of burned lime was charged to 840 grams of green liquor. During the course of four hours, 8 grams of white liquor was sampled 10 times.

The density of the green liquor was measured using a pipette $(50 \mathrm{ml})$ and a balance; at $90^{\circ} \mathrm{C}$, it was found to be $1150 \mathrm{~kg} / \mathrm{m}^{3}$.

Slaking and causticizing, carried out in a KGW-Isotherm 1.0 liter Dewar-flask agitated at $300+/-10 \mathrm{rpm}$ with IKA RW20 mixing equipment according to DIN EN 459-2. The temperature increase was measured with a TESTO 735-2 temperature data logger.

\section{Results and Discussion}

\section{Granulation in the lime kiln}

Samples of burned lime taken on different occasions were analyzed by sieving in order to quantify the influence of the particle/granule size on the degree of dusting in the hot end of the lime kiln. Fig 1 - displays the sieving results obtained from a typical burned lime from both a dusting and a clear lime kiln. The most important differences that can be found here is in the fraction of fines $(<1 \mathrm{~mm})$ and the fraction larger than $15 \mathrm{~mm}$. 


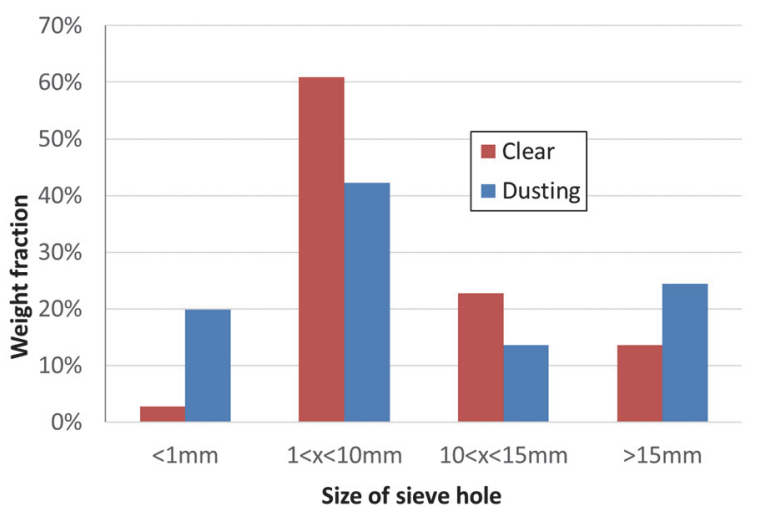

Fig 1 - The weight fractions obtained from sieving burned lime from a clear and a dusting lime kiln.

Table 1 - Sieving burned lime. The temperature of the burned lime over the discharge dam is measured by a spyrometer (optical measurement), and the thermocouple located under the burner is also included.

\begin{tabular}{llcccc}
\hline Description & Date & $\begin{array}{c}\text { Spyr. } \\
{ }^{\circ} \mathbf{C}\end{array}$ & $\begin{array}{c}\text { Therm. } \\
{ }^{\circ} \mathbf{C}\end{array}$ & $\begin{array}{c}<1 \\
\mathbf{m m}\end{array}$ & $\begin{array}{c}10<\mathbf{x}<15 \\
\mathbf{m m}\end{array}$ \\
\hline Dusting & $26 / 3$ & 889 & 802 & $49.7 \%$ & $4.6 \%$ \\
Dusting & $14 / 4$ & 958 & 811 & $19.9 \%$ & $13.6 \%$ \\
Dusting & $15 / 4$ & 894 & 736 & $12.7 \%$ & $13.8 \%$ \\
Dusting & $8 / 5$ & 851 & 850 & $38.2 \%$ & $10.0 \%$ \\
Dusting & $5 / 8$ & 943 & 895 & $16.4 \%$ & $20.0 \%$ \\
Little dusting & $18 / 5$ & 1051 & 754 & $8.9 \%$ & $14.2 \%$ \\
Clear & $7 / 4$ & 1148 & 878 & $3.2 \%$ & $23.8 \%$ \\
Clear & $8 / 4$ & 1134 & 866 & $2.8 \%$ & $22.7 \%$ \\
Clear & $9 / 4$ & 1145 & 850 & $2.5 \%$ & $22.4 \%$ \\
Clear & $30 / 6$ & 1201 & 888 & $2.7 \%$ & $22.2 \%$ \\
Clear & $20 / 11$ & 1175 & 803 & $1.1 \%$ & $27.3 \%$ \\
\hline
\end{tabular}

Data from the sieving analyses, along with the corresponding temperatures measured, are shown in Table 1 .

The temperature of the lime bed was measured by a spyrometer (optical measurement) and a thermocouple was mounted just under the burner. The temperature measured by the thermocouple was influenced by the temperature of the surrounding gas, as well as by radiation from the lime bed and the flame. In the case of the dusting lime kiln, between 10 and $50 \%$ of the particles passed through a $1 \mathrm{~mm}$ sieve, whereas up to $10 \%$ was in the range of 10 to $15 \mathrm{~mm}$. For a clear lime kiln, only a few percent passed the $1 \mathrm{~mm}$ sieve, and $25 \%$ was between 10 and 15 $\mathrm{mm}$.

The temperature measured by the spyrometer is much lower at dusting conditions than clear conditions. This is due to the fact that the spyrometer is mounted outside the kiln, i.e. there is a long distance between the sensor and measuring target. In dusting conditions, the spyrometer therefore measures the temperature of the dusting particles rather than that of the surface of the lime bed. However, the temperature measured by the thermocouple does not show any systematic difference between clear and dusting conditions, thereby indicating that the temperature conditions are about the same. It should nevertheless be kept in mind that some shielding effect can be expected in dusting conditions in the case of the thermocouple, too. It is present but, compared to the spyrometer, the distance is much shorter and the effect of shielding is, therefore, much smaller

\section{Chemical composition}

Samples of lime mud, burned lime and the ESP dust were taken on 11 occasions, and the contents of the most common elements analyzed, in order to investigate whether the differences in dusting are caused by variations in chemical composition. The results are presented in Appendix A, Table A1. One trend is that the concentrations of sodium and potassium seem to be higher in the ESP dust during dusting periods. The other elements, for instance iron and aluminum, show no obvious correlation between dusting in the lime kiln and elemental composition. The elevated concentrations of sulphur detected in the samples from some of the occasions are due to methanol (with accompanying sulphur-containing compounds) being fired in the lime kiln.

A useful way of comparing the chemical content in burned lime, lime mud and ESP dust is to calculate the enrichment factor $a$ which is the ratio between the normalized concentration of an element in the ESP dust and the lime mud, $E q 3$. In this work, the concentration of calcium was used to normalize all other elements.

$$
a_{\text {element }}=\frac{\left(\frac{c_{\text {element }}}{\left.{ }^{c_{C a}}\right)_{\text {burned lime or ESP-dust }}}\right.}{\left(\frac{{ }^{\text {element }}}{{ }^{c} \text { Ca }}\right)_{\text {lime mud }}}
$$

The enrichment factor provides information of how the concentration of various elements changes in the different material streams in the lime kiln.

The results of the calculations of the enrichment factor, $a$, are shown in Appendix A. Table A2 shows that sulphur, sodium, phosphorous, silicon and potassium are enriched in the ESP dust, whereas the enrichment factor is close to one for magnesium and aluminum. In the case of iron, the enrichment factor is lower than one; for zink, enrichment factors both above and below one were obtained. The results show that sodium and potassium in ESP dust are more enriched in a dusting lime kiln than in a clear kiln, with potassium being more enriched than sodium. No correlation was found, however, between water-soluble sodium and dusting (results not shown).

One plausible reason for the enrichment of sodium is the formation of sodium hydroxide in the gas phase at the hot end of the lime kiln, according to $E q 4$ by Tran et al. (1991):

$$
\left(2 \mathrm{Na}^{+}, \mathrm{CO}_{3}{ }^{2-}\right)(\text { smelt })+\mathrm{H}_{2} \mathrm{O}(\mathrm{g}) \leftrightarrow 2 \mathrm{NaOH}(\mathrm{g})+\mathrm{CO}_{2}(\mathrm{~g})
$$

Sodium hydroxide in the gas phase reacts with $\mathrm{CO}_{2}$ or $\mathrm{SO}_{2}$ to form $\mathrm{Na}_{2} \mathrm{CO}_{3}$ or $\mathrm{Na}_{2} \mathrm{SO}_{4}$ (Lidén \& Pejryd, 1986). The $\mathrm{Na}_{2} \mathrm{CO}_{3}$ and/or $\mathrm{Na}_{2} \mathrm{SO}_{4}$ condense and fine fume particles are formed that can easily be entrained in the flue gas and carried to the ESP.

Potassium is vapourized and reacts analogously to sodium. The partial pressure for $\mathrm{KOH}$ is even higher than that of $\mathrm{NaOH}$ (Hupa 1997; Lidén, Pejryd, 1986), so the 
enrichment of potassium species in ESP dust is therefore likely to be even higher than for sodium: this is in accordance with the results in Appendix A, Table A2.

The enrichment of phosphorus in the ESP dust is consistent between 1.5 and 2 except for the sample from May $18^{\text {th }}$, where the enrichment factor was 3.1. The reason for this being high is most likely that the charge of makeup lime was much greater on just that occasion. The enrichment of phosphorus is probably not due to the vaporization mechanism explained above, since the degree of volatilization of phosphorus is very small up to $1100{ }^{\circ} \mathrm{C}$ (Zhang et al. 2012).

\section{Particle size distribution}

The particle size distribution was measured for the wet lime mud and the ESP dust; the results are reported in Table 2 and a representative example of the distributions is shown in Fig 2 -.

The particle size of wet lime muds shows no distinct correlation to the tendency of dusting in the hot end of the lime kiln. The size of the ESP dust is influenced by the velocity of the flue gas and the density of the lime mud: a high velocity and a low density lead to a large fraction of lime mud being carried over to the ESP. The size of the ESP dust also shows no correlation to the tendency of dusting.

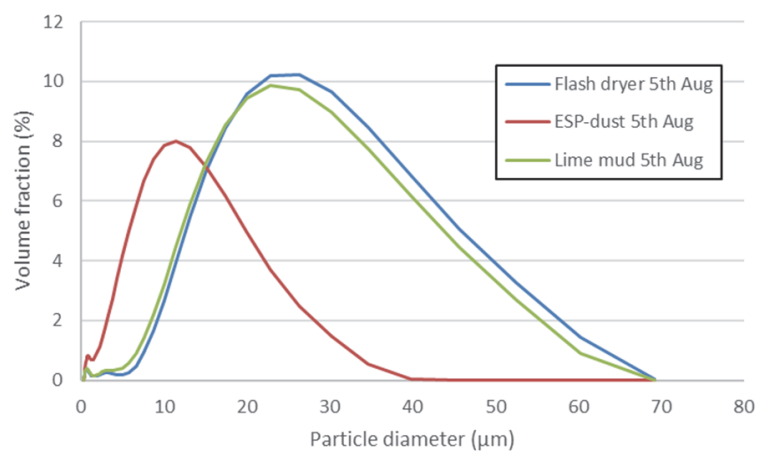

Fig 2 - Typical particle size distribution of wet lime mud, lime mud from the flash dryer and ESP dust from a dusting lime kiln.

Table 2 - Particle size distribution of wet lime mud and ESP dust.

\begin{tabular}{|c|c|c|c|c|c|c|c|c|c|c|c|c|c|c|c|c|}
\hline \multirow[t]{2}{*}{ Descr. } & \multirow[t]{2}{*}{ Date } & \multicolumn{3}{|c|}{ Lime mud } & \multicolumn{3}{|c|}{ ESP dust } & & & & & & & & & \\
\hline & & $d_{10}$ & $d_{50}$ & $\mathrm{~d}_{90}$ & $d_{10}$ & $d_{50}$ & $\mathrm{~d}_{90}$ & \multirow{3}{*}{\multicolumn{9}{|c|}{$\begin{array}{l}\text { Table } 3 \text { - Chemical composition of samples of burned lime (fines } \\
\text { and granules) taken on four different occasions during } 2015 \text {. }\end{array}$}} \\
\hline Dusting & $26 / 3$ & 7.8 & 18.5 & 35.0 & 1.8 & 7.7 & 17.0 & & & & & & & & & \\
\hline Dusting & $14 / 4$ & 7.8 & 17.9 & 33.9 & 2.7 & 12.0 & 34.8 & & & & & & & & & \\
\hline Dusting & $15 / 4$ & 7.9 & 18.1 & 34.1 & 2.3 & 9.1 & 20.0 & \multicolumn{3}{|c|}{$\begin{array}{c}\text { 5th Aug } \\
\text { (dusting) }\end{array}$} & \multicolumn{2}{|c|}{$\begin{array}{l}\text { 28th Aug } \\
\text { (dusting) }\end{array}$} & \multicolumn{2}{|c|}{$\begin{array}{c}\text { 2nd Sept } \\
\text { (clear) }\end{array}$} & \multicolumn{2}{|c|}{$\begin{array}{l}\text { 10th Sept } \\
\text { (clear) }\end{array}$} \\
\hline Dusting & $8 / 5$ & 8.6 & 21.2 & 39.9 & 2.3 & 9.4 & 21.2 & $\mathrm{~g} / \mathrm{kg}$ & Gran. & Fine & Gran. & Fine & Gran. & Fine & Gran. & Fine \\
\hline Dusting & $5 / 8$ & 7.8 & 18.9 & 35.4 & 1.9 & 8.6 & 19.4 & $\mathrm{Ca}$ & 655 & 653 & 654 & 670 & 677 & 698 & 647 & 632 \\
\hline & שות & 1.0 & 10.5 & 0.4 & 1.5 & 0.0 & 19.4 & $\mathrm{Na}$ & 11.8 & 10.9 & 11.8 & 11.9 & 12.4 & 12.8 & 12.1 & 12.6 \\
\hline $\begin{array}{l}\text { Little } \\
\text { dusting }\end{array}$ & $18 / 5$ & 5.7 & 17.8 & 37.9 & 1.9 & 7.7 & 18.5 & $\begin{array}{l}\mathrm{K} \\
\mathrm{Mg}\end{array}$ & $\begin{array}{l}0.7 \\
12.3\end{array}$ & $\begin{array}{c}0.5 \\
12.1\end{array}$ & $\begin{array}{c}0.6 \\
11.8\end{array}$ & $\begin{array}{c}0.4 \\
11.7\end{array}$ & $\begin{array}{l}0.4 \\
13\end{array}$ & $\begin{array}{c}0.4 \\
12.7\end{array}$ & $\begin{array}{c}0.6 \\
13.6\end{array}$ & $\begin{array}{c}0.6 \\
13.2\end{array}$ \\
\hline Clear & $7 / 4$ & 8.1 & 21.6 & 41.2 & 2.5 & 9.0 & 20.0 & $\mathrm{Al}$ & 0.7 & 0.8 & 0.7 & 0.7 & 0.6 & 0.8 & 0.7 & 0.9 \\
\hline Clear & $8 / 4$ & 8.6 & 21.2 & 39.9 & 2.3 & 9.4 & 21.2 & $\mathrm{Fe}$ & 0.4 & 0.4 & 0.4 & 0.4 & 0.3 & 0.3 & 0.3 & 0.4 \\
\hline Clear & $9 / 4$ & 8.3 & 20.1 & 37.7 & 29 & 96 & 200 & $\mathrm{Zn}$ & 0.9 & 0.4 & 0.4 & 0.5 & 0.5 & 0.5 & 0.6 & 0.5 \\
\hline & & & & & & & 20.0 & SI & 2.6 & 3.2 & 3.3 & 2.8 & 1.9 & 2.2 & 2.7 & 3.1 \\
\hline Clear & $30 / 6$ & 7.8 & 18.9 & 35.4 & 1.9 & 8.6 & 19.4 & $P$ & 9.6 & 9.8 & 10.5 & 11 & 11.9 & 12 & 12.8 & 12.7 \\
\hline Clear & $20 / 11$ & 7.7 & 19.1 & 36.3 & 2.2 & 9.1 & 19.8 & S & 2.4 & 1.7 & 1.7 & 2.0 & 1.1 & 1.4 & 2.3 & 2.5 \\
\hline & & & & & & & & C & 1.0 & 1.3 & 1.6 & 1.3 & 0.8 & 2.0 & 1.2 & 1.9 \\
\hline
\end{tabular}

\section{Comparison between granules and fines}

Different fractions of burned lime were slaked and reactivity. The chemical composition of the various fractions was also analyzed. The samples of burned lime collected on August $5^{\text {th }}$, August $28^{\text {th }}$, September $2^{\text {nd }}$ and September $10^{\text {th }}$ were sieved, and granules ranging from 10 to $15 \mathrm{~mm}$ were collected, along with fines fractions smaller than $1 \mathrm{~mm}$.

\section{Chemical composition}

According to Tran (2016), a high sodium content causes a low-reactive, dead, burned lime whereas a low sodium content causes dusting. The findings of Magnusson (1977) also indicate that sodium decreases dusting by lowering the surface charge that inhibits agglomeration. Granules can therefore be expected to have a higher sodium content than fines. The chemical compositions in Table 3, however, show very similar results for the granular lime and the fines.

In fact, the fines actually had a higher sodium content than the granules for three out of four sampling dates.

There is a notable increase of phosphorous with time, implying a high degree of closure without any purging of the ESP dust occurring.

\section{Reactivity when slaking in water}

The initial reaction in the causticizing operation is the exothermic reaction of $\mathrm{CaO}$ with water, generating $\mathrm{Ca}(\mathrm{OH})_{2}$. Studying the temperature rise during this reaction provides information regarding the reactivity of the lime. The characteristics of the exothermic reaction is determined by slaking a smaller amount of lime in demineralized water with an initial temperature of $20^{\circ} \mathrm{C}$. At this low temperature, the heat losses from the lime slaking system are small, and the temperature increase measured can be compared to the theoretical temperature rise due to the exothermal slaking reaction. The results in Table 4, obtained from a $15 \mathrm{~g}$ sample of burned lime slaked in $750 \mathrm{~g}$ of demineralized water for 4 hours, indicate that the fines fraction is less reactive than the granules. causticized with the aim of investigating differences between the fines fraction and the granules in terms of 
Table 4 - Analysis of burned lime (granules and fines).

\begin{tabular}{|c|c|c|c|}
\hline $\begin{array}{l}15 \mathrm{~g} \text { lime in } \\
750 \mathrm{~g} \text { water }\end{array}$ & $\begin{array}{l}\Delta \mathrm{T}_{\text {measured }} \\
{ }^{\circ} \mathrm{C}\end{array}$ & $\begin{array}{l}\Delta \mathrm{T}_{\text {theoretical }} \\
{ }^{\circ} \mathrm{C}\end{array}$ & $\begin{array}{l}\text { Free } \mathrm{CaO} \\
\mathrm{w} \%\end{array}$ \\
\hline Granules 5/8 & 4.4 & 4.8 & 87.6 \\
\hline Fines 5/8 & 4.1 & 4.7 & 86.3 \\
\hline Granules $2 / 9$ & 4.5 & 4.9 & 88.4 \\
\hline Fines 2/9 & 4.2 & 4.8 & 87.1 \\
\hline Granules $10 / 9$ & 4.4 & 4.9 & 88.7 \\
\hline Fines 10/9 & 4.1 & 4.8 & 85.6 \\
\hline
\end{tabular}

The slaking curves are very similar to each other. A representative example is shown in Fig 3 - where the shape of the curves is also in agreement with the results obtained by Hanson and Theliander (1994).

Fig 3 shows that the difference between the rise in the measured and theoretical temperatures is larger for the fines than for the granules. This implies that a smaller percentage of the free $\mathrm{CaO}$ reacts in the fines than in the granules. It is interesting that the inserted graph in Fig 3 (of the first 30 seconds) shows that the fines are more reactive during the first phase of the slaking reaction. The reason for the granules appearing to be less reactive during the initial phase is probably related to their surface area being smaller prior to disintegration (i.e. the reaction is limited by the transportation of water in the granules). Once the granules begin breaking apart, however, the surface area and reactivity that become available exceeds those of the fines. Similar results were obtained for the burned lime taken from August $5^{\text {th }}$ and $28^{\text {th }}$ and September $10^{\text {th }}$.

\section{Reactivity when slaking in green liquor}

The burned lime fractions from August $5^{\text {th }}$ and $28^{\text {th }}$, and September $2^{\text {nd }}$ and $10^{\text {th }}$, were also added to $840 \mathrm{~g}$ of synthetic green liquor. The aim here was to assess not only the yield of $\mathrm{NaOH}$ but also the overall causticizing rate, so the causticizing tests were performed using a large excess of carbonate ions. The results reported in Table 4 were used to calculate the $\mathrm{CaO}$ content of the granules and fines to ensure that the same amount of $\mathrm{CaO}$ was added to the green liquor when the granules and fines are compared.

Fig 4 --7 show the increase in effective alkali in the four slaking experiments with reburned lime fines compared with reburned lime granules with a similar $\mathrm{CaO}$ content and chemical composition. They also show the increase in temperature during the first $30 \mathrm{~min}$ of the reaction.

In all of the cases shown, the fines fraction is less reactive, has a lower yield of effective alkali and a smaller temperature rise than the granular lime. These results are in agreement with the results of Rydin, et al., (1977).

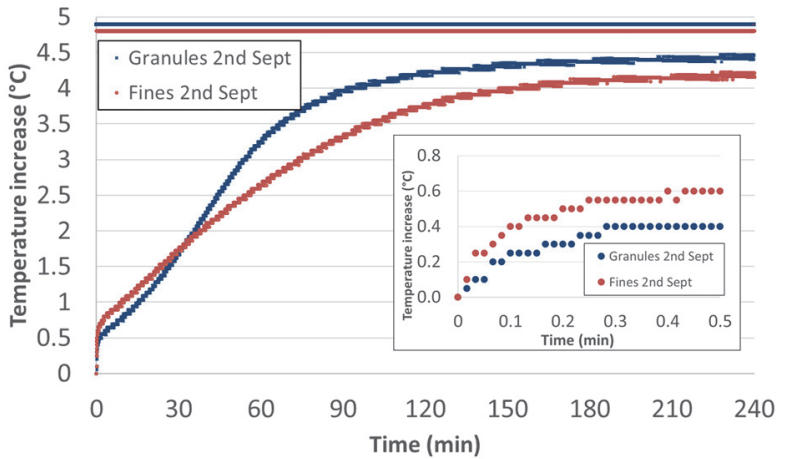

Fig 3 - Temperature rise during the slaking of burned lime in deionized water, with the heat rise due to energy input from the agitation subtracted. The insertion shows the phase during the initial 30 seconds.

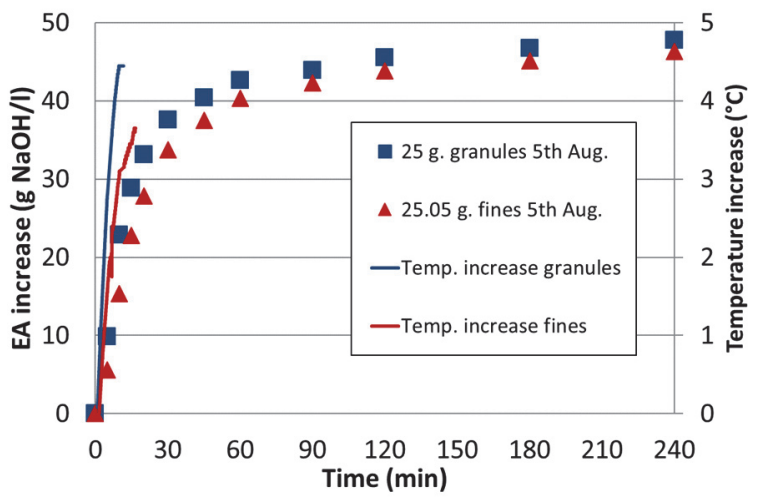

Fig 4 - Burned lime in the form of granules and fines slaked in synthetic green liquor. Samples taken on August $8^{\text {th }} 2015$ from a dusting lime kiln.

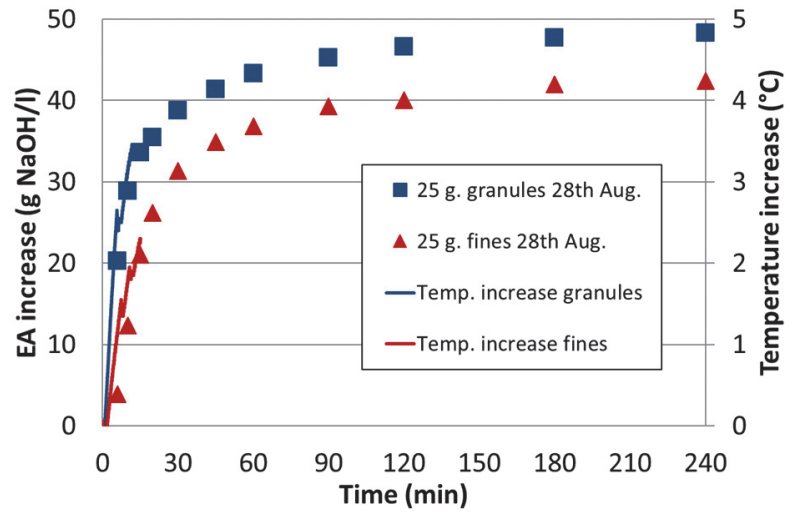

Fig 5 - Burned lime in the form of granules and fines slaked in synthetic green liquor. Samples taken on August 28 2015 from a dusting lime kiln. 


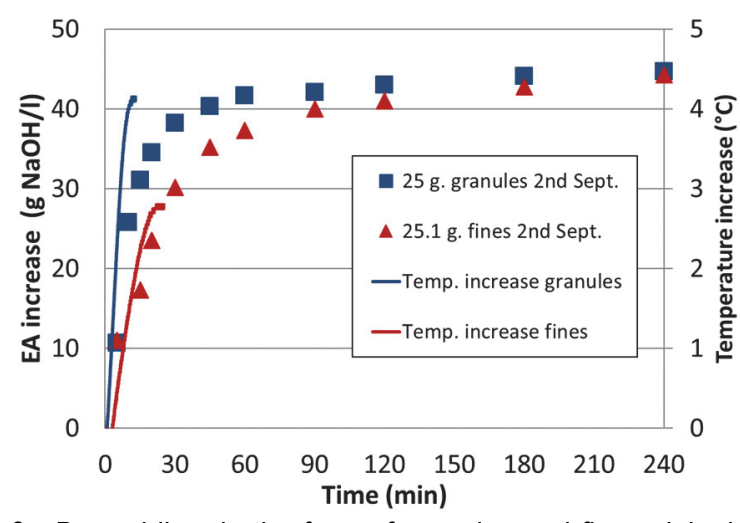

Fig 6 - Burned lime in the form of granules and fines slaked in synthetic green liquor. Samples taken on September $10^{\text {th }} 2015$ from a clear lime kiln.

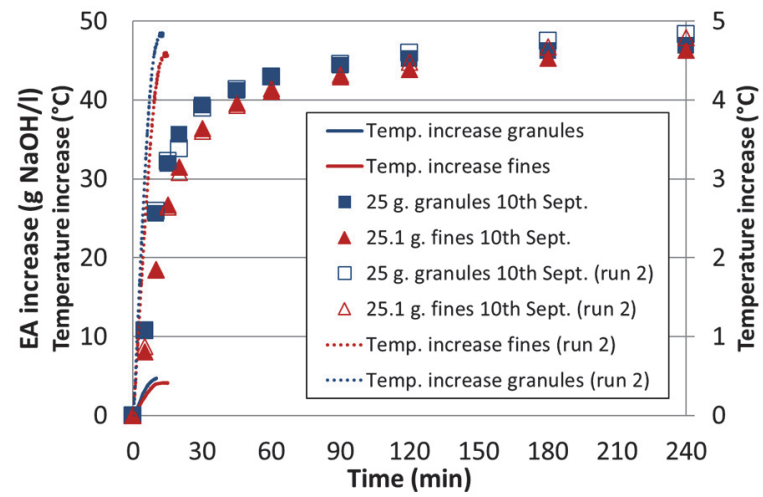

Fig 7 - Burned lime in the form of granules and fines slaked in synthetic green liquor. Samples taken on September $10^{\text {th }} 2015$ from a clear lime kiln.

\section{Particle size distribution and specific surface area - after causticizing}

The particle size distribution and specific surface area obtained for the wet lime mud in the laboratory causticizing experiments were measured (Table 5 -).

The general tendency is that the lime mud comprised of fines has larger particles and a smaller specific surface area than that comprised of granules. This implies that the fines fraction is, in fact, more sintered. It is consistent with the reactivity results that were obtained, as presented above.

It is worth noting that the results of the September $10^{\text {th }}$ samples showed that the burned lime fines had a higher surface area than the granules while still displaying the same low increase in EA as the other limes. The experiment was therefore performed twice, but the second result showed no great difference in the size of the surface area between the granules and the fines. All of the particle size measurements nonetheless showed a consistent difference: the lime mud composed of fines has larger particles than that composed of granules.

The results of the particle size distribution reported in Table 5 - indicate that extensive inter-particle sintering in the fines fraction forms dense and stable aggregates that are more durable. It can also be observed that the average particle size and the specific surface area of the lime muds are in agreement with the results obtained by Hanson and Theliander (1994).
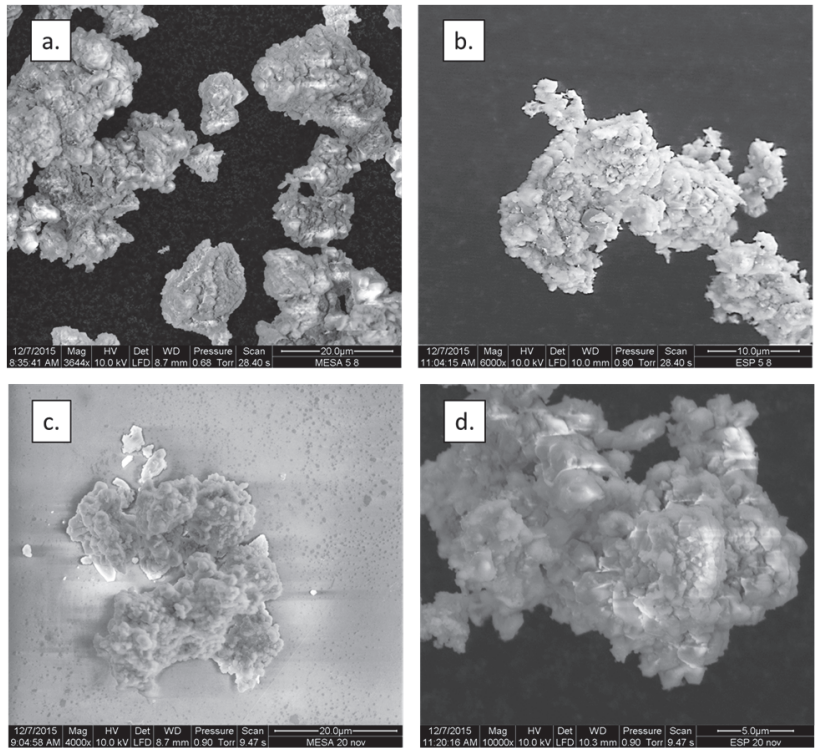

Fig 8 - Samples of lime mud (a) and ESP dust (b) taken from a dusting lime kiln on August $5^{\text {th }}$. Samples of lime mud (c) and ESP dust (d) taken from a clear lime kiln on November $20^{\text {th }}$.

Table 5 - Specific surface area of the burned lime used in the reactivity tests. $\left(^{*}\right)$ indicate a second analysis.

\begin{tabular}{|c|c|c|c|c|c|c|}
\hline $\begin{array}{l}\text { Burned lime } \\
\text { sample }\end{array}$ & $\begin{array}{l}\text { Dusting/ } \\
\text { Clear }\end{array}$ & $\begin{array}{l}\text { BET } \\
\mathrm{m}^{2} / \mathrm{g} \\
\text { Lime }\end{array}$ & $\begin{array}{l}\text { BET } \\
\mathrm{m}^{2} / \mathrm{g}\end{array}$ & $\begin{array}{l}\mathrm{d}_{10} \\
\boldsymbol{\mu m}\end{array}$ & $\begin{array}{l}d_{50} \\
\mu \mathrm{m} \\
\text { forme }\end{array}$ & $\begin{array}{l}d_{90} \\
\mu m\end{array}$ \\
\hline Fines Aug.5 & Dusting & 0.17 & 2.3 & 7.7 & 15.2 & 26.5 \\
\hline Granules Aug.5 & Dusting & 0.23 & 4.4 & 6.0 & 13.3 & 24.4 \\
\hline Fines Aug.2 & Dusting & 0.27 & 2.9 & 6.3 & 14.0 & 37.2 \\
\hline Gran. Aug.28 & Dusting & 0.29 & 2.7 & 6.0 & 13.1 & 24.0 \\
\hline Fines Sept.2 & Clear & 0.22 & $2 . \overline{4}$ & 6.8 & 16.7 & 40.8 \\
\hline Gran. Sept.2 & Clear & 0.44 & 3.1 & 4.5 & 12.4 & 31.4 \\
\hline Fines Sept.10 & Clear & 0.72 & 3.4 & 5.1 & 12.4 & 25.9 \\
\hline Gran. Sept.10 & Clear & 0.41 & 3.1 & 4.8 & 12.2 & 23.8 \\
\hline Fines Sept.10_2 & Clear & $0.27^{*}$ & $2 . \overline{6}$ & 5.5 & 12.8 & 27.0 \\
\hline Gran. Sept.10_2 & Clear & $0.25^{*}$ & 3.1 & 5.5 & 12.7 & 24.5 \\
\hline
\end{tabular}

\section{Structure of the particles}

Samples of wet lime mud, ESP-dust, burned lime fines and granules from a dusting lime kiln taken on August $8^{\text {th }}$ were investigated using ESEM, along with samples of wet lime mud, ESP dust and burned lime granules taken from a clear kiln on November $20^{\text {th }}$.

Images $a$ and $c$ in Fig 8 show lime mud with an approximate particle diameter of about $20-40 \mu \mathrm{m}$; images $b$ and $d$ show some typical ESP dust particles with an approximate diameter of about 5-15 $\mu \mathrm{m}$. A general observation made in the ESEM study was that the lime mud particles were notably larger than the ESP dust particles. This is in agreement with the results given in Table 2, where the average particle size was 18.9 and 19.1 $\mu \mathrm{m}$ for the lime mud and 8.6 and 9.1 for the ESP dust. 


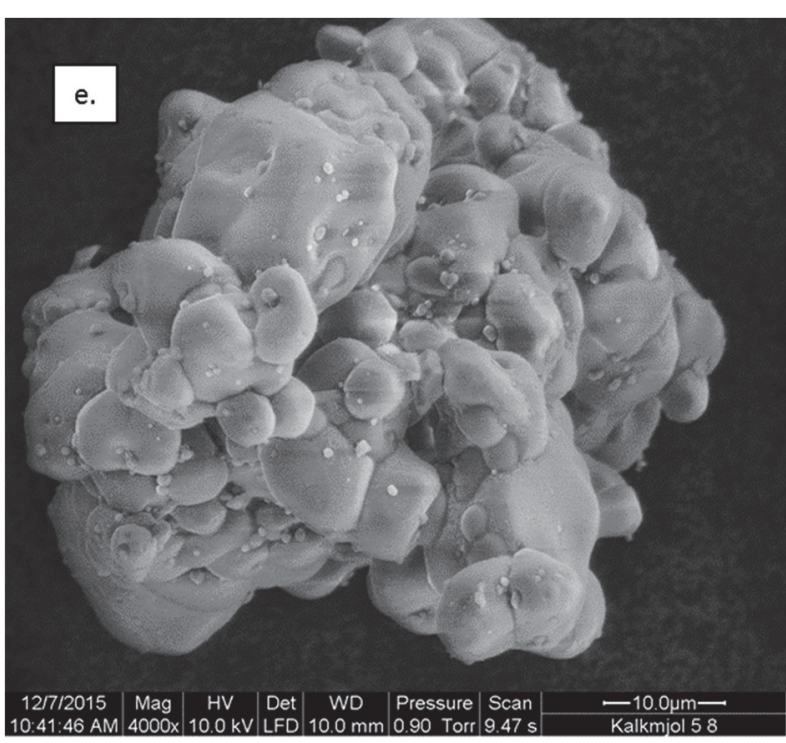

Fig 9 - A fines fraction of burned lime from a dusting lime kiln August $5^{\text {th }}$.

Fig 9 - shows a fines fraction of burned lime, with an agglomerate size of around $50 \mu \mathrm{m}$.

Fig 10 shows a granule fraction of burned lime. It can be seen that more small particles are attached to the surface of the burned lime from the clear kiln (taken on November $20^{\text {th }}$ ) than from the dusting kiln (taken on August $5^{\text {th }}$ ). It may also be noted that the surfaces of the fines in Fig 9 are more rounded and even than those of the granules in Fig 10, indicating that the fines are harder sintered. Furthermore, the granules show more signs of crystal structures (Hanson, Theliander,1994).

\section{Effects of ESP dust removal}

The hypothesis was assumed that ESP dust influences dusting behaviour in the hot end of a lime kiln since dusting in this location is accompanied by the occurrence of a large fines fraction of burned lime and a large fraction exceeding $15 \mathrm{~mm}$ (cf. Fig 1 -). Mill experiments were therefore conducted on three occasions, when ESP dust was removed from the lime cycle. The evacuation was carried out using a vacuum truck, with the amount of ESP dust retrieved being measured by weighing the truck before and after loading. The increase in the truck's weight was monitored by noting its axle pressure once an hour. The three occasions in question were when the lime kiln was clear, dusting and between dusting and clear, i.e. "a little dusting".

Evacuating the ESP dust resulting in the lime kiln becoming clearer on the two occasions that the kiln was dusting; no difference was made on the occasion when the kiln was clear. Weighing the ESP dust showed that, when the lime kiln was clear, $4.5 \%$ of the dry substance incoming lime mud was circulated over the ESP. When it was dusting, $11 \%$ was circulated and, when it was in between, $8 \%$ was circulated.

When the ESP dust from the lime cycle was removed, the fraction of fines in the burned lime decreased. An example of this is shown in Fig $11-$, where the fraction of fines in the burned lime decreased from $16 \%$ to $6 \%$ by weight.
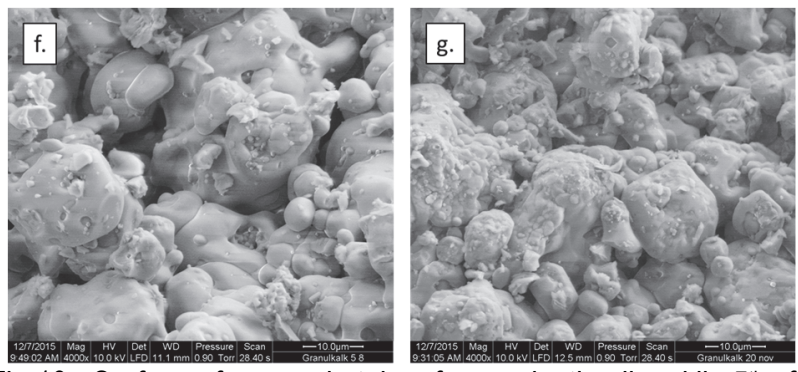

Fig 10 - Surface of a granule taken from a dusting lime kiln $5^{\text {th }}$ of August $(\mathrm{f})$ and a clear lime kiln $20^{\text {th }}$ of November $(\mathrm{g})$.

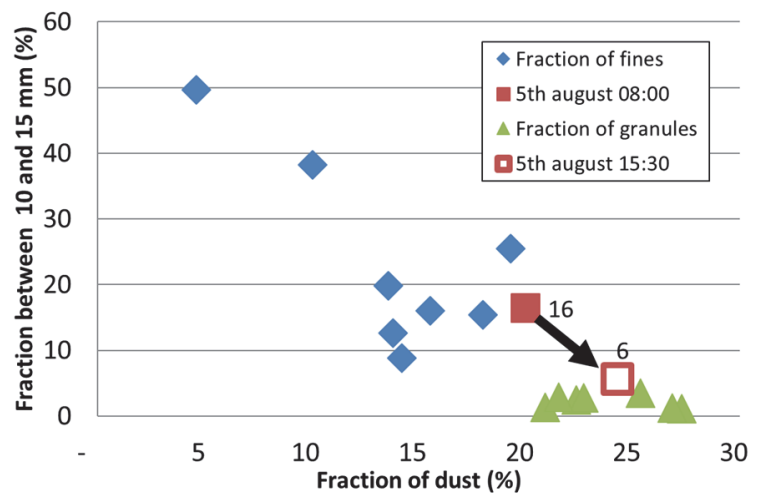

Fig 11 - The effect of removing ESP dust from the lime cycle on August 8th. The data plotted is from Table 1.

One tentative explanation for the decrease in dusting in the hot end of the lime kiln when ESP dust was removed could be related to the way ESP dust influences the formation of agglomerates already at the cold end. It was noted that, when the ESP dust and lime mud from the flash dryer were handled, the fine particulate ESP dust agglomerated upon tumbling in room temperature, whilst the coarse particulate lime mud from the flash dryer did not. The reason for this remains to be investigated.

\section{Conclusions}

Wet lime mud from a dusting lime kiln is likely to contain larger particles than that from a clear kiln because the fines fraction is more sintered. The larger particles decrease the filtration resistance and promote a high dryness from the lime mud filter. This is in line with the experience of the mill upon installing lifters in the lime kiln.

The ESP dust from a dusting lime kiln is considerably enriched with sodium and potassium.

The quality of the burned lime in terms of reactivity and yield of $\mathrm{NaOH}$ is lower for the burned lime fines compared to the lime granules. One effect of a dusting lime kiln is, thus, a decrease in the performance of the causticizing plant.

\section{Acknowledgments}

Financial support received from Södra Skogsägarnas Stiftelse för Forskning, Utveckling och Utbildning is gratefully acknowledged. Special thanks go to the valuable work, patience and understanding of the staff at the Södra Cell Mönsterås Mill. 


\section{Literature}

Fardadi, M., (2010): Modeling Dust Formation in Lime Kilns, Ph. D. Thesis, University of Toronto, Toronto, Canada.

Hanson, C. and Theliander, H., (1994a): Properties and quality of lime - Part 1. The influence of conditiond during reburning. Nord. Pulp Paper Res. J., 9(3), 161-166.

Hanson, C. and Theliander, H., (1994b): Properties and quality of lime. Part 3. Influence on slaking, causticizing and filtreation processes. Nord. Pulp Paper Res. J., 9(3), 226-231.

Hupa, M. (1977): Recovery Boiler Chemistry. In Adams, T. (ed.) Kraft Recovery Boilers, Tappi Press, Atlanta (GA), USA, pp. 3956.

Kassberg, M. and Petersson, B., (1997): Vitlutsberedning (White Lliquor Peparation, in Swedish), Skogsindustrins Utbildning i Markaryd AB, Markaryd, Sweden, 5th (revised) ed. ISBN:91-7322-225-9.

Lidén, J. and Pejryd, L., (1986): Chlorine emission from recovery boilers. Nord. Pulp Paper Res. J., 01(1), 22-25.

Lindblom, J., Wildt, J. and Theliander, H., (1998): Sintering of calcined lime mud - the influence of sodium and sulphate content in the lime, Nord. Pulp Paper Res. J., 19(11), 23-30.

Magnusson, H., (1977): Mesaugnens kemi: emission av svavelväte och svaveldioxid. (Chemistry of the Lime Kiln: Emission of Hydrogen Sulphide and Sulphur Ddioxide), (in Swedish). SCAN Forskrapport $\mathrm{nr}$ 132. Availabre from RISE Bioeconomy, Stockholm, Sweden.

Mao, X. and Tran, H.: (2016): Measurement of free lime content in lime mud. Tappi J. 14(7), 481-489.

Rydin, S., Haglund, P. and Mattson, E: (1977) Causticizing of technical green liquors with various lime qualities. Svensk papperstidning, 80(2), pp. 54-58.

Sixta, H., (2006): Introduction, In: Sixta, H. (ed), Handbook of Pulp Vol. 2, Wiley-VCH Verlag GmbH, Weinheim, Germany, pp. 986-988.

Tran, H., Griffiths, J. and Budge, M., (1991): Experience of lime kiln ringing problems at E.B. Eddy Forest Products, Pulp Paper. Can., T26-30.

Ulmgren, P., (1997): Non-process elements in a bleached kraft pulp mill with a high degree of system closure - state of the art, Nord. Pulp Paper Res. J., 19 (11), 32-42.

Zhang, Q., Liu, H., Li, W., Xu, J. and Liang, Q. (2012): Behavior of Phosphorus during Co-gasification of Sewage Sludge and Coal, Energy Fuels, 26(5), 2830-2836.

Manuscript received June 10, 2016 Accepted February 14, 2017 


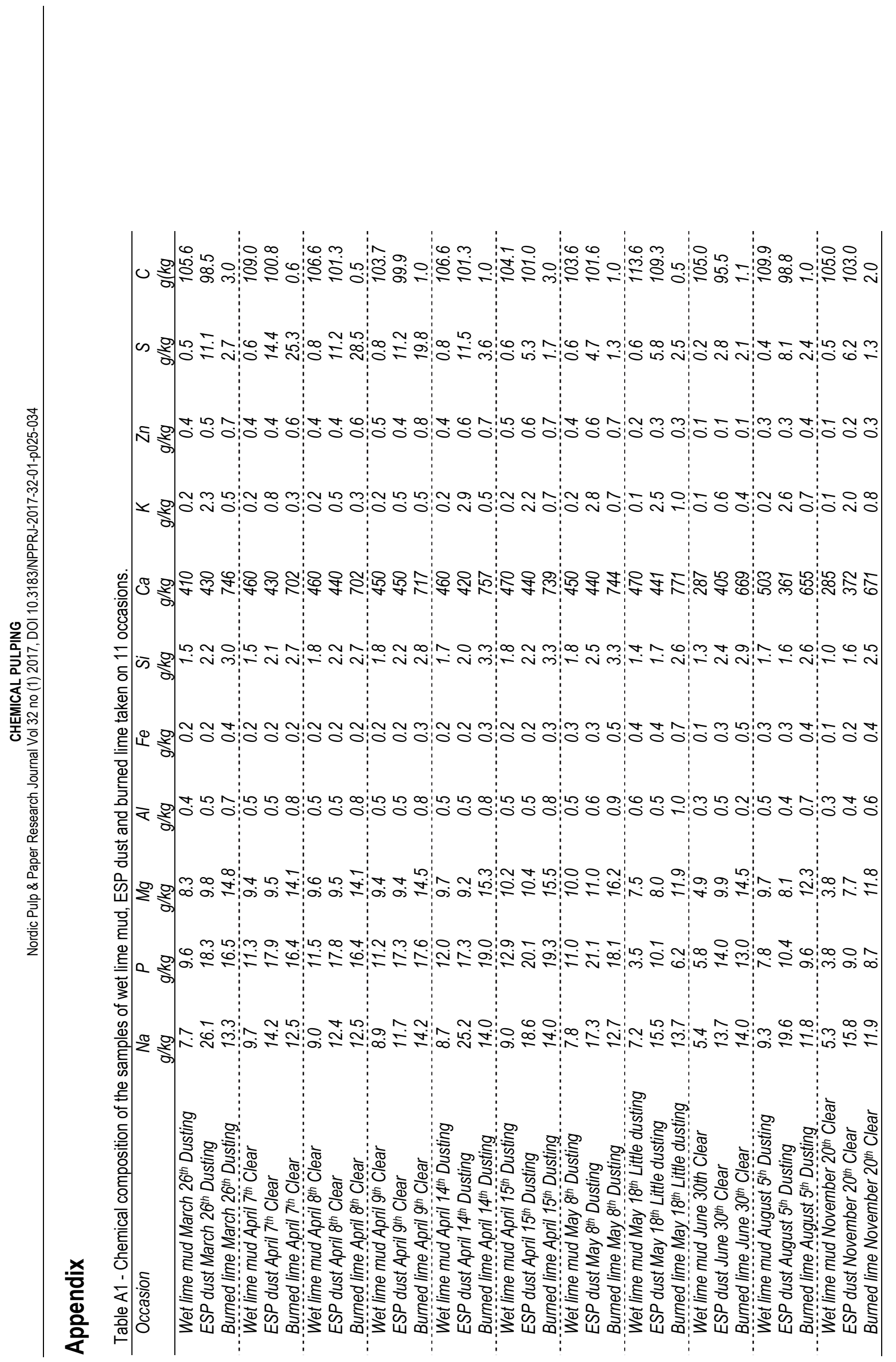




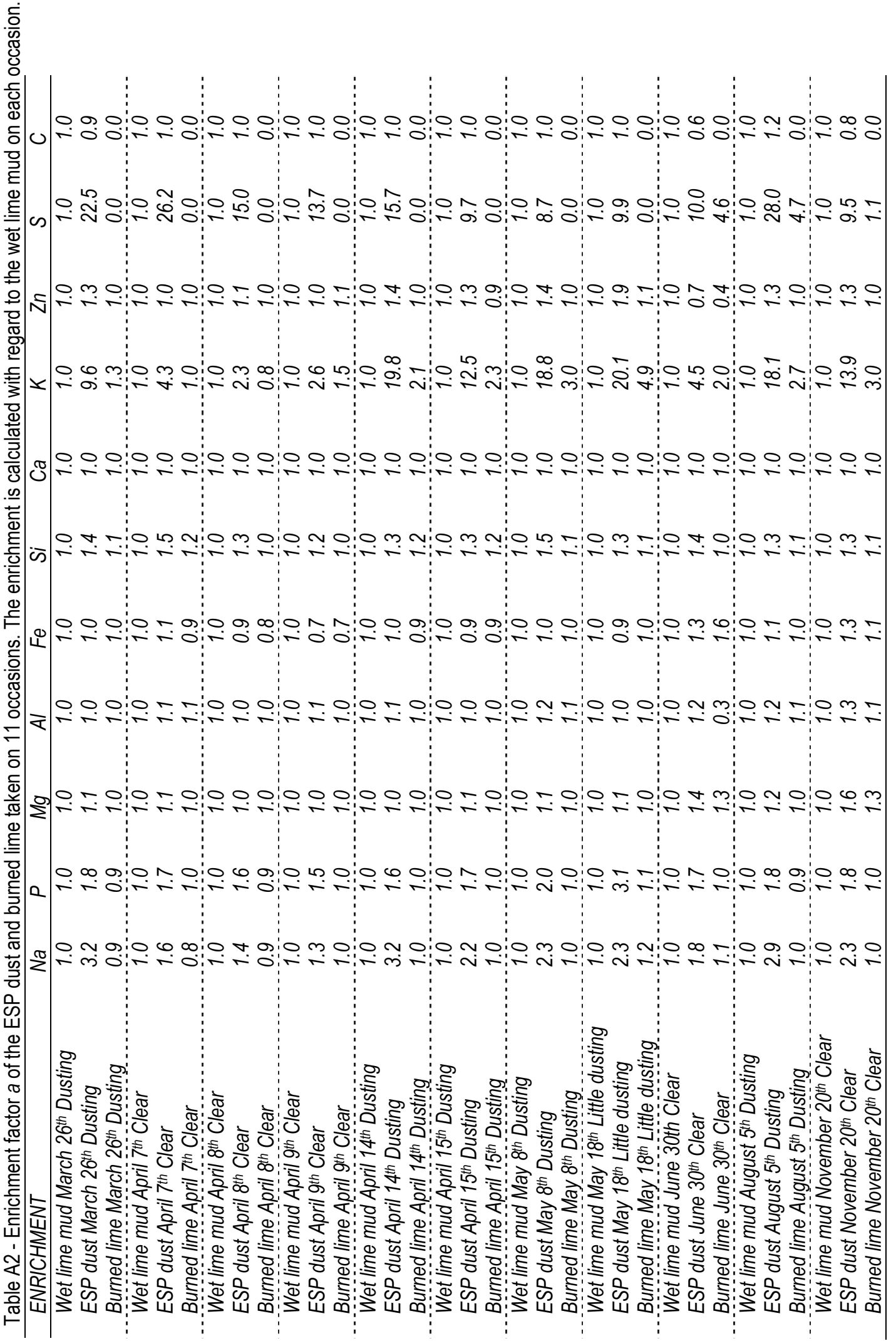

